\title{
Technical Efficiency of Maize in District Lakki Marwat of Khyber Pakhtunkhwa, Pakistan
}

\author{
Aftab Khan ${ }^{1}$, Shahid Ali ${ }^{*}$, Asim Khan ${ }^{1}$, Muhammad Waqas ${ }^{1}$ and Sufyan Ullah Khan ${ }^{2}$
}

${ }^{1}$ Department of Agricultural and Applied Economics, The University of Agriculture, Peshawar, Khyber Pakhtunkbwa, Pakistan; ${ }^{2}$ College of Economics and Management, Northwest $A$ and F University, Shaanxi, China.

Abstract | This study aimed at estimating and examining technical efficiency of maize farms in Southern areas of Khyber Pakhtunkhwa-Pakistan. It utilized the primary data collected from 320 maize farms randomly selected through multistage sampling. Parametric technique of stochastic frontier production function was estimated to model output of maize growers. Results of stochastic frontier model revealed that tractor hours, labor and FYM positively and significantly affected yield of maize. Average technical efficiency was predicted to be 0.68 ranging from 0.31 to 0.91 ; implies that an average maize farm can increase yield by 33 percent with existing technology. Technical inefficiency effect model identified that education and farming experience has negative and significant effect on farmers' inefficiency. It is recommended that maize farmers need to be provided with formal as well as informal education, agricultural trainings and credit on easy terms for purchase of costly inputs.

Received | August 04, 2019; Accepted | February 13, 2020; Published | April 20, 2020

*Correspondence | Shahid Ali, Department of Agricultural and Applied Economics, The University of Agriculture, Peshawar, Khyber Pakhtunkhwa, Pakistan; Email: drshahid@aup.edu.pk

Citation | Khan, A., S. Ali, A. Khan, M. Waqas and S.U. Khan. 2020. Technical efficiency of maize in district Lakki Marwat of Khyber Pakhtunkhwa, Pakistan. Sarbad Journal of Agriculture, 36(2): 402-410.

DOI | http://dx.doi.org/10.17582/journal.sja/2020/36.2.402.410

Keywords | Maize, Technical efficiency, Stochastic frontier production function, Southern Khyber Pakhtunkhwa

\section{Introduction}

A griculture is the mainstay of the economic system of Pakistan and it accounted for $18.90 \%$ contribution in GDP. It employed labor force approximately $42.3 \%$ in the Pakistan's economy and have major role in foreign exchange earnings. Over all significant growth was recorded 3.81 percent to the previous year growth of 2.07 percent in agriculture (GOP, 2018).

As increase in agriculture production aids to decrease destitution in the rural area and improve the livelihood of people and drive the economic growth that generates productive employment, and raises income (DFID, 2018). GDP growth originates from agriculture sector has three times more efficacious in reducing poverty than any other sector in the economy mostly poor people live in the rural area relying on farming sector and agriculture contributes to one third GDP of the world (GAFSP, 2017).

The significant cereal crop of grass family (Graminae) recognized as Maize (Zea mays L.), its production was started from central and South America frequently known as corn, and in older period of time it was utilized by the people. In all grains maize has an important position, and therefore it has been ranked third after wheat and rice. Maize is primarily utilized for the nourishment purpose, basically for the family utilization but with passage of time its usage is not only restricted to the importance of food but also 
for the mechanical purpose. All around the world the maize production is quickly spreading, it is now grown in many countries due to its characteristics of adaptability and profitability (Singh et al., 2003).

The world widely, during 2017 maize production recorded to be 1134.74 Million Metric Tons on the allocated area of 197 Million Hectares having an average yield of $5754.7 \mathrm{~kg} / \mathrm{ha}$. Highest maize producer country is USA 370.96 (MMT) followed by China 259.23 (MMT), Brazil 97.72 (MMT), Argentina 49.47 (MMT) and India 28.72 (MMT). Pakistan ranked $22^{\text {nd }}$ highest maize producer in the world and its total production was 5.7 (MMT) and cultivated on the total area of 1.3 million hectares and having yield of $4636.4 \mathrm{~kg} / \mathrm{ha}(\mathrm{FAO}, 2017)$.

In Pakistan the production of maize was recorded to be 5.702 Million Tons on the allotted area of 1.2 Million Hectares 7\% decline in the production has been observed due to the decline of 8.8 percent area to the previous year. The contribution of maize to the value addition is 2.4 percent in agriculture and 0.5 percent to GDP. (GOP, 2018).

In Pakistan all provinces produce maize, Punjab is the highest Maize producer with 5237.1 thousand tons and area utilized was 868.2 thousand hectares and yield of $6032 \mathrm{~kg} / \mathrm{ha}$. The second highest maize producer province is KP with the production of 890.1 thousand tons on area of 473.4 thousand hectare and yield $1880 \mathrm{~kg} / \mathrm{ha}$ followed by Sindh and Baluchistan (GOP, 2017).

Maize is main crop grown in Khyber Pakhtunkhwa Districts. The Agriculture Statistics of Pakistan estimated that area under crop has slightly been increased from the previous year in Khyber Pakhtunkhwa. The allocated area in 2016 was 468.5(000) hectares which was increased to 473.4(000) hectares in 2017. However, the estimated output in Thousand Tonnes has considerably been increased from 873(000) tonnes in 2016 to 890.1 (000) tonnes in 2017. While throughout the statistics of agriculture shows that there is up and downs in the allocated area and production of maize (GOP, 2017)

The land in Khyber Pakhtunkhwa is very fertile and suitable for growing maize but the yield of maize is still less than Punjab and it can be improved by technical efficiency. The well-known area of Khyber
Pakhtunkhwa is Lakki Marwat. In Lakki marwat the allocated area under maize decreased, in 2016 the estimated cropped area recorded was 916 (HA) which is recently declined to 554 (HA) in 2017. Furthermore, as the estimated area decreased, it declined the output as well the estimated production was 1768 (tonnes) in 2016 decreased to 1028 (tonnes) in 2017 and yield of Lakki Marwat was $1856 \mathrm{~kg} / \mathrm{ha}$ (GOKP, 2018). Presumably due to less area utilization the output has been decreased. The low yield of Lakki Marwat is probably due to feeble cultivation strategies, technical inefficiency of farmers, substandard production technology, depletion of soil fertility, ineffective management practices, inconsistent pattern of rainfall, Immense use of unimproved seeds, under and over usage of inputs and less utilization of fertilizer and agro chemical. In such situations enhancing technical efficiency probably is the satisfactory way to elevate the maize production.

The growth rate is less as compared to increase in population every year. Consequently, it is necessary to enhance the efficiency of maize growers in order to meet the local demand and save foreign exchange (Ali et al., 2019). The technological advancement particularly in agriculture sector, has brought an enhancement in efficiency and productivity (Ugochukwu and Phillips, 2018). By improving skill development, managerial practices and education that could be a factors to increase the productivity by the efficient way of utilizing technology and resources. (Fatima et al., 2016).

The potentiality of new innovation and advantages can be realized when it is adopted and utilized (Uaiene, 2011). The potentiality of the growers to get maximum permissible output with in accessible resources is the technical efficiency. However only through adaptation and innovative technologies the target growth in production could not be achieved, but mainly through the efficiency in which technologies are utilized. By this way policy makers and researcher realize the significance of efficiency as a way of increasing production. Empirical proof from different research suggests that the gap between actual and potential output can be closed by the utilization of less inputs to gain a possible maximum output. (Bempomaa and Acquah, 2014) Pursuing of different management practices by the farmers is the reason of variation in production. The possibility of achieving efficiency in productivity is realized by 
technical efficiency and level of inefficiency factors in maize (Ali et al., 2019).

Most farmers utilizing similar inputs but still its outputs are distinctive due to differences in managing practices used by the farmers or utilization of inefficient inputs. This inefficiency is named as technical inefficiency and characterized as the inability to accomplish the greatest conceivable production within accessible technology and resources (Farrell, 1957).

In developing countries for increasing production great exertion need to be done for enhancing and wise usage of the present technology that might be more cost effective rather than discovering the brand new technology furthermore, the wise use of inputs would lead to increase profit and eventually advance the farmer economic condition and livelihood (Saptoka et al., 2017). The study aimed to investigate the socio economic, technological and other factors which affect T.E of maize producer in Lakki marwat and offer them an opportunity to enhance their production. Though no research is carried out on technical efficiency in Lakki marwat that's why this research is planned to gauge the technical efficiency in this region which give assistance to the policy makers to start program relative to the maize production.

\section{Materials and Methods}

\section{Study universe}

This study investigated T.E in District Lakki Marwat, Khyber Pakhtunkhwa-Pakistan. Lakki Marwat is split in 2 Tehsil i.e., Tehsil Lakki Marwat and Serai Nawrang. There are 31 union council in Lakki Marwat (Figure 1). Arid and semi- arid Climatic condition are present in the region. The average annual precipitation is recorded $300 \mathrm{~mm}$. it is enclosed by Districts Bannu, Karak, D.I. Khan, Tank, and South Waziristan Agency. In rural populace agriculture is considered as the main source of living. The total area in Lakki Marwat comprises of 3164 sq. $\mathrm{km}$ and number of people per unit area is found to be 238 person per sq. $\mathrm{km}$, while the total area under cultivation is 116,900 hectares. Furthermore, their total population is 753572 during 2011-2012 (GOP, 2012).

\section{Sampling technique and sample size}

The technique of multistage were chosen to select the famer's sample in the district. In this technique first step is to divide the district Lakki Marwat into two tehsils namely tehsil Naurang and Lakki Marwat. In stage second, from each tehsil four specifically Tajazai, Abba Khel, Ghanzi Khel from tehsil Lakki and Kot Kashmir. Shakh Quli Khan, Mama Khel, Gandi Khan Khel were leading producing towns were chosen area. In the final stage 40 producers of maize were chosen randomly from each town through technique of proportional allocation (Cochran, 1977) given as under:

$$
n_{i}=n^{x}\left(N_{i} / N\right)
$$

\section{Whereas,}

$n_{i}=$ Maize farmers chosen from ith village; $n=$ Total maize farmers in sample, $N_{i}=$ Total maize farmers in selected village; $N=$ Total maize farmers in all selected villages (Table 1 ).

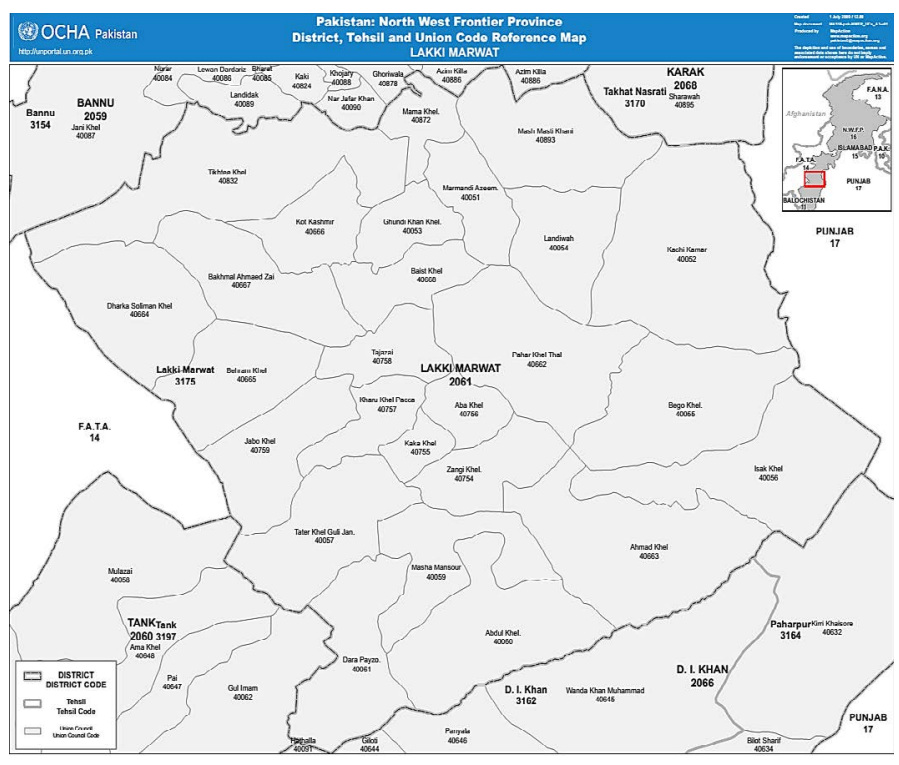

Figure 1: District Lakki Marwat map of, KPK, Pakistan.

\section{Sources of the data}

This study exercised both secondary and primary data. Questionnaire was arranged to gather the primary data of the Variables like age education fertilizer, maize output, farm size, area etc. Through different statistics like Economic Survey of Pakistan, Agricultural Statistics of Pakistan and Development Statistics of Khyber Pakhtunkhwa were the main sources of secondary data.

\section{Theoretical frame work}

Farmer efficiency is highly dynamic to economist to contract how to escalate output with the available input. The estimation of efficiency and output Productivity were implied first by Koopmans (1951), which was advanced by Farrell (1957). Further Farrell June 2020 | Volume 36 | Issue 2 | Page 404 
classify economic efficiency into three main types namely economic efficiency, technical efficiency and allocative efficiency. Technical efficiency provides statistics concerning variation that subsists amongst farmer's production. Essentially measures the gap between farmer's actual yield and the yield that can be produced by consuming the farm capitals efficiently. The allocative efficiency is attaining maximum output by using cost minimizing input.

\section{Model specification}

There are two approaches used to estimate technical efficiency parametric and non-parametric. Nonparametric approach which also known data envelopment analysis is the mathematical approach which used for technical efficiency while other paramatic approach dealt with econometrics procedure. However, both methodologies have it virtues and drawbacks as Battese (1992) elucidated the pros and cons of the given models. While parametric model is stochastic that hold discrete random error from technical inefficiency while non paramatic has the random noise and technical inefficiency unruffled. Paramatic model restricts the misspecification of functional and the non paramatic is less responsible to such conclusion.

Stochastic frontier production function given in Equation 1 was self-sufficiently premeditated by Aigner et al. (1977). The perfect form of the model can be explained as.

$$
Y_{i}=f\left(X_{i} ; B\right)+e_{i} i=1,2,3, \ldots \ldots . . n
$$

Where;

$Y_{i}=$ maize yield in kg's/acre; $f()=$ Appropriate $\mathrm{ftn}$; $A_{i}=$ Input cast - off in maize yield (units/acre); $B=$ Coefficient to be assessed.

$$
e_{i}=v_{i}-u A
$$

Where;

$e_{i}=$ Error term (composite); $v_{i}=$ Random error with mean zero; $\mu_{i}=$ Non-negative condensed half normal.

The error influence, $v$, signify random effects, misplaced independent variables and measurement errors. The $2^{\text {nd }}$ error factor, $\mu_{i}$ is specific farm factor, having connotation with farm technical in-efficiency it ranges grown 0 to 1 (Khan, 2012).

Table 1: Sampling technique and sample size.

Tehsil Towns Sampled villages

Lakki Taja zai

Zatoon khel

Hasan khel

Rajo Khel

Sub total

Abba

khel

Jawboo khel

Gul Banda

Sub total

Ghanzi Dothar

Khel

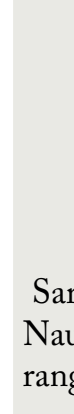

Sari
Nau-
rang

(2)

$\begin{array}{llll}\text { Shakh } & \text { Kota machan khel } & 20.00 & 10.67 \approx 11 \\ \text { Quli } & \text { Kota Jangi khan } & 30.00 & 16.00 \approx 16 \\ \text { Khan } & \text { Kashmir khel } & 25.00 & 13.33 \approx 13 \\ & \text { Sub total } & 75.00 & 40.00 \\ \text { Mama } & \text { Sheri Khel } & 20.00 & 8.51 \approx 8 \\ \text { Khel } & \text { Mala kali } & 25.00 & 10.64 \approx 11 \\ & \text { Siffat Khel } & 18.00 & 7.66 \approx 8 \\ & \text { Ismail Khel } & 31.00 & 13.19 \approx 13 \\ & \text { Sub total } & 94.00 & 40.00 \\ \text { Gandi } & \text { Nor Kuli khan } & 50.00 & 25.32 \approx 25 \\ \text { Khan } & \text { Nor hakim khan } & 29.00 & 14.68 \approx 15 \\ \text { khel } & \text { Sub total } & 79.00 & 40.00 \\ & \text { G.Total } & 746.00 & 320.00\end{array}$

Source: Govt. of Khyber Pakhtunkhwa, 2018.

\section{Empirical model}

Maize output was modeled as Cobb-Douglas production form stated in Equation 2.

$\ln (Y)=B_{0}+B_{1} \ln S_{1}+B_{2} \ln S_{2}+B_{3} \ln S_{3}+B_{4} \ln S_{4}+B_{5} \ln S_{5}+B_{6} \ln S_{6}+B_{7} \ln S_{7}+\varepsilon_{i}$

Where;

In $=$ Natural log; $y=$ yield of maize; $S_{1}=$ Area ( $\left.\mathrm{kg} / \mathrm{acre}\right)$; $S_{2}=$ Tractor hour; $S_{3}=$ Labor man days; $S_{4}=$ DAP in kgs; $S_{5}=$ Urea in kg's; $S_{6}=$ Hybrid seed as Dummy; $S_{7}=$ FYM as Dummy; $\varepsilon_{i}=$ error term and demarcated as $v_{i}-\mu_{i}, v_{i}=$ Random error; $\mu_{i}=$ technical inefficiency error; $B_{0}=$ constant; $B_{1}=$ coefficient of regression. 
Inefficiency model can be specified as:

$$
u_{i}=\delta_{0}+\delta_{1} W_{1}+\delta_{2} W_{2}+\delta_{3} W_{3}+\delta_{4} W_{4}+\omega_{i}
$$

Where;

$W_{1}=$ Farmer's age; $W_{2}=$ Farming experience; $W_{3}=$ Famer's education $\omega_{i}=$ Random error term; $\delta_{i}=$ Coefficients.

The assessment of technical efficiency of separate maize producers, formula is mentioned in Equation 4.

$$
T E_{i}=Y_{i} / Y_{i}^{*}
$$

Whereas,

$Y_{i}=$ Perceived output of individual farmer; $Y_{i}^{*}=$ Output attained at frontier; $T E_{i}=$ Individual farmer's technical efficiency and it ranges from 0 to 1 .

For technical inefficiency of singular grower, the formula is given in Equation 5.

$$
T l i=1-T E_{i}
$$

\section{Results and Discussion}

\section{Variables summary statistics}

Table 2 depicts the summary statistics of all those variables employed in econometric model. The recorded average yield is $511.12 \mathrm{~kg}$ with standard deviation 2.74 ranging from 49.40 to 13600.00 . The average cultivated land under maize is 1.35 acre fluctuating from 0.12 to 19.99 with deviation of 2.25 . Similarly, the mean machinery hours have 2.78 with standard deviation 1.5 ranging from 0.74 to 7.56 . Likewise, the labour average was 15.18 with the lower of 3.33 while highest of 25 with 1.53 standard deviation. The average DAP user were $18.39 \mathrm{Kg}$ with standard deviation of 2.68 ranges from 3.99 to 50.00 $\mathrm{kg}$ per acre.

The average urea used by the farmers was 55.11 with standard deviation of 2.57 ranging from 5 to 549.99 . The mean ages of the maize growers were 48.85 with 12.86 standard deviation from total number of farmers osculate from 23 to 69 years. The calculated average experience of the farmers were 24.75 along with 15.25 standard deviation ranges from of 2 to 50 years. The mean calculated value of education was 5.73 having standard deviation of 6.23 ranging from 0 to
16 year. The dummy variables has been incorporated in the model which mean value indicates that $43 \%$ have used hybrid and $23 \%$ used Farm Yard Manure.

Table 2: Variables summary statistics.

$\begin{array}{llllll}\text { Variables } & \text { Units } & \text { Mean } & \text { Std. Dev. } & \text { Min. } & \text { Max. } \\ \text { Yield } & \mathrm{kg} & \mathbf{9 2 8} & \mathbf{2 . 7 4} & \mathbf{5 5 4} & \mathbf{1 8 5 6} \\ \text { Area } & \text { acre } & 1.35 & 2.25 & 0.12 & 19.99 \\ \text { Tractor } & \mathrm{hrs} & 2.78 & 1.62 & 0.74 & 7.56 \\ \text { Labor } & \mathrm{MD} & 15.18 & 1.53 & 3.33 & 25.00 \\ \text { DAP } & \mathrm{kg} & 18.39 & 2.68 & 3.99 & 50.00 \\ \text { Urea } & \mathrm{kg} & 55.11 & 2.57 & 5.00 & 549.99 \\ \text { Hybrid } & \text { dummy } & 0.43 & 0.42 & 0 & 1 \\ \text { FYM } & \text { dummy } & 0.23 & 0.42 & 0 & 1 \\ \text { Age } & \text { years } & 48.85 & 12.86 & 23.00 & 69.00 \\ \text { Experience } & \text { years } & 24.75 & 15.25 & 2.00 & 50.00 \\ \text { Education } & \text { years } & 5.73 & 6.23 & 0.00 & 16\end{array}$

Source: Authors' estimates from survey data, 2018.

\section{MLE results}

Table 3 indicates the estimated model of the technical efficiency. The MLE results shows that elasticity of area was significant at 1 percent and have negative effect on yield of maize. The negative influence on maize yield in response to increase in area may be due to insufficient availability of budget for purchase of costly inputs such as DAP, urea and hybrid seed. The coefficient of area is -1.032 ; this means that one percent increase in area by farmers leads to decrease yield by 1.032 percent. Estimated coefficients of tractor, labor and FYM were 0.193, 0.344 and 0.435, respectively and statistically significant at $1 \%$. This implies that as result of one percent increase in these factors, maize yield increase by $0.193 \%, 0.344 \%$ and $0.435 \%$, respectively. Coefficients of DAP and urea were only 0.029 and 0.013 and significant at $10 \%$. Hybrid seed has insignificant effect on maize output.

Table 3: MLE results.

\begin{tabular}{lllrlll} 
Variables & Units & \multicolumn{2}{c}{$\begin{array}{l}\text { Param- } \\
\text { eters }\end{array}$} & $\begin{array}{l}\text { Coeffi- Std. } \\
\text { cients }\end{array}$ & $\begin{array}{l}\text { trrors } \\
\text { ratios }\end{array}$ & $\begin{array}{l}\text { P- } \\
\text { value }\end{array}$ \\
Constt. & & $\beta_{0}$ & 5.254 & 0.150 & 34.99 & $0.000^{-* *}$ \\
Ln Area & Acre & $\beta_{1}$ & -1.032 & 0.025 & -41.32 & $0.000^{-* *}$ \\
Ln Tractor & $\mathrm{Hrs}$ & $\beta_{4}$ & 0.193 & 0.038 & 5.04 & $0.000^{-*}$ \\
Ln Labor & $\mathrm{MD}$ & $\beta_{2}$ & 0.343 & 0.048 & 7.10 & $0.000^{-* *}$ \\
Ln DAP & $\mathrm{Kg}$ & $\beta_{3}$ & 0.029 & 0.016 & 1.83 & $0.067^{*}$ \\
Ln Urea & $\mathrm{Kg}$ & $\beta_{5}$ & 0.031 & 0.017 & 1.78 & $0.074^{*}$ \\
Hybrid seed & Dummy & $\beta_{6}$ & 0.066 & 0.043 & 1.53 & $0.126^{\text {ns }}$ \\
FYM & Dummy & $\beta_{7}$ & 0.435 & 0.050 & 8.57 & $0.000^{*-*}$
\end{tabular}

Source: Authors estimate, survey data, 2018. 
Note: ** and *indicating significance at 1 and $5 \%$, respectively.

Technical inefficiency effects model

Table 4 presents estimated results of technical inefficiency effects model. Results revealed that age has negative but insignificant effect on inefficiency of maize yield. Similarly, Farmers experience has negative influence on technical inefficiency of maize output and was found significant at 1 percent level. This implies that those farmers were technically more efficient who had more years of farming experience than those who had less years of experience. Farming experience provides more knowledge and help to make correct decisions in production environment. Moreover, education had also negative sign and statistically significant at the $1 \%$ which implies that those maize growers were technically more efficient who had more education than those who had less. Education play vital role in agriculture, farmers with education have the opportunity of make better decisions about technology use, input prices, and are more talented to understand market needs. The coefficient shows that education increase by one year will decrease inefficiency by 58 percent. The results of maximum likelihood estimate described variance parameter that is gamma with a value of 0.58 exposed that out of total variation in production 58 percent is due to technical inefficiency, $\mathrm{u}$, of the farmers and the remaining 42 percent is due to natural uncertainty factor, $v$.

Table 4: Technical inefficiency effects model.

\begin{tabular}{lllllll} 
Variables & \multicolumn{2}{c}{$\begin{array}{c}\text { Unit } \\
\text { earam- Coeffi- Std. } \\
\text { eters }\end{array}$} & $\begin{array}{l}\text { t. ratios } \\
\text { cients }\end{array}$ & $\begin{array}{l}\text { Prrors } \\
\text { value }\end{array}$ \\
Constant & & $\delta_{0}$ & 0.0 .16 & 0.539 & 0.030 & $0.765^{\text {ns }}$ \\
Age & Year & $\delta_{1}$ & -0.001 & 0.011 & $-0.140^{\text {ns }}$ & 0.887 \\
Experience & Year & $\delta_{2}$ & -0.086 & 0.180 & -4.80 & 0.000 \\
Education & Year & $\delta_{3}$ & -0.547 & 0.116 & $-4.71^{* *}$ & 0.000 \\
Return to scale & & & 0.065 & & & \\
Average TE & & $\mathrm{X}_{\text {mean }}$ & 0.68 & & & \\
Min TE & & $\mathrm{X}_{\min }$ & 0.36 & & & \\
Max TE & $\mathrm{X}_{\max }$ & 0.91 & & &
\end{tabular}

\section{Variances parameters}

$\begin{array}{llll}\text { Sigma }-U & \sigma_{\mathrm{u}} & 0.470 & 0.609 \\ \text { Sigma }-V & \sigma_{\mathrm{v}} & 0.199 & 0.339 \\ \text { Sigma square } & & 0.2609 & 0.445 \\ \text { Lambda } & & 2.354 & 0.969 \\ \text { Gamma } & . \gamma & 0.58 & \\ \begin{array}{l}\text { Log likelihood } \\ \text { ratio }\end{array} & & -28.97 & \end{array}$

Source: Estimated from survey data, 2018; Note: ** and *indicates significance at $1 \%$ and $5 \%$ probability, respectively.

The returns to scale value of 0.031 shows increasing returns to scale. The production of the maize is operating in the 1st stage of production function. Therefore, revealing that those variables whose inputs utilization increase in the production process would lead to increase production more than proportionate. The average technical efficiency estimated 67 percent with minimum 31 to maximum 91 percent.

\section{Individual technical efficiencies}

Figure 2 shows technical efficiency of the farmers below $100 \%$ or 1 , showing that all the selected maize growers in the Lakki marwat District produce under the frontier. The average technical efficiency level is nearby $68 \%$. A large range of variation occurs in the scores of technical efficiency of the maize growers with 132 (41.25\%) lies in between 61-70 percent as the highest score. The respondents with $92(28.75 \%)$ the total selected sampled were $71-80$ percent efficiency. Likewise, efficiency level of 57 (17.81\%) farmers were 51-60 Percent. The least portion of farmers 3 (0.93), $20(6.25 \%)$ and $16(5 \%)$ with efficiency levels $31-50$, 81- 90, and 91-100 percent respectively. This infers that in the sample if the means respondents would like to reach the effectiveness level of its most efficacious counterpart, then mean respondents would rise maize production by 25 percent [i.e., $1-(62 / 88)=0.2527$ ] Likewise, the most technically inefficient respondent could improve maize production by 60 percent [i.e., $1-(34 / 88)=0.6048]$.

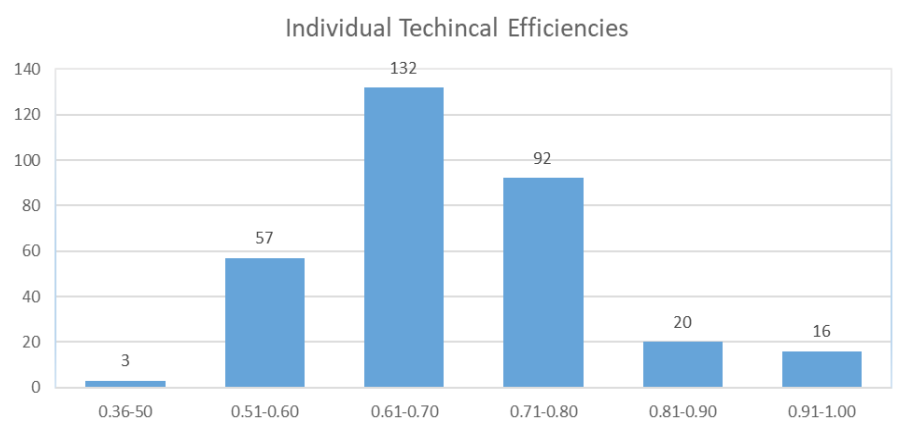

Figure 2: Individual technical efficiencies.

Source: Authors estimates from survey data, 2018.

The MLE results of the production factors revealed a great impact on maize productivity. The negative coefficient of the area indicates the inverse relation with maize yield. The negative relationship between cropping area and yield has also been observed by Chirwa (2007). Owens (2003) also argued that there is inverse relationship between local maize yield and area but a positive relationship in a hybrid 
maize model. But these results are in contrast to the findings of Anupama et al. (2005), Bravo-Ureta and Pinheiro (1997), Geffersa et al. (2019), Geta et al. (2013), Gouse et al. (2009), Kidane and Ngeh (2015), as they found the positive relationship between area and yield, whereas according to Kamau (2019) area has insignificant effect on maize productivity which may be due to overuse and more expansion of the area which led to a decrease in the increase of marginal output. The tractor hours has significant and positive relationship which reveal that tractors hours has very important component in achieving higher yield. These findings are also supported by Chirwa (2007), Geffersa et al. (2019). Labor has significant positive effect on maize productivity. These results are in accordance with the findings of Anupama et al. (2005), Bravo-Ureta and Pinheiro (1997), Geta et al. (2013), Gouse et al. (2009). Labor is considered to be the primary factor of production and is a very important input which enhance the yield of maize crop. Increasing labor utilization in maize production in operations such as land preparation, planting, fertilizer application, weeding and harvest would significantly increase maize productivity because of their significant utilization. Some of the studies e.g., Geffersa et al. (2019), Kamau (2019), Kidane and Ngeh (2015), among others, found no significant effect of labor input on maize output. Farm yard manure and chemical fertilizer had significant and positive impact on maize yield which shows that farmers who use fertilizer receive higher maize yields. Hence increase in the efficient level of fertilizer usage would ultimately rise maize production. These findings are in line with results obtained by Anupama et al. (2005), Bravo-Ureta and Pinheiro (1997), Geffersa et al. (2019), Geta et al. (2013), Gouse et al. (2009), Kidane and Ngeh (2015). Hybrid seed has insignificant effect on maize production due to its demand for excessive water availability as cropping hybrid seed require appropriate irrigation system (Kamau, 2019).Whereas some studies Chirwa (2007) proved the negative relationship between hybrid seeds utilization and maize production. These results are in contrast to the findings of Geffersa et al. (2019), Geta et al. (2013), Gouse et al. (2009).

There is negative association between farmer age and technical inefficiency and are statistically significant that shows that an increase in farmers' age decreases the technical inefficiency. These result are in line with the findings of Kamau (2019) while different from
Geffersa et al. (2019) and Kidane and Ngeh (2015). There is negative and significant relationship of farmer experience with technical inefficiency; implies that an increase in farmer experience the technical inefficiency decreases. These results are supported by Chirwa (2007) while contradictory with (Kamau, 2019). Education play vital role in maize production. There has negative association of education technical inefficiency which demonstrates that education can decrease the farmer inefficiency level. These result are in line with (Gouse et al., 2009) and opposed to that from (Kamau, 2019).

\section{Conclusions and Recommendations}

It is concluded that tractor hours, labour and FYM have positive and significant influence on maize which indicates that maize output rises by $0.193 \%, 0.344 \%$ and $0.435 \%$, respectively, in response to $1 \%$ increase in these inputs. The estimated elasticity of area was found negative and significant at 1\%. DAP, Urea and Hybrid seed has insignificant effect on maize yields. In inefficiency effects model, education and farming experience has negative and significant effect on farmers' inefficiency. Besides, age of the farmers have negative but insignificant effect on inefficiency of farmers. It is recommended that maize farmers need to be provided with formal as well as informal education, agricultural trainings and credit on easy terms for purchase of costly inputs.

\section{Novelty Statement}

This study estimated technical efficiency of maize growers in Southern Khyber Pakhtunkhwa of Pakistan using stochastic frontier production function. Findings of this study provide insights for maize farmers and policy makers for boosting up production of maize in the province.

\section{Author's Contribution}

Aftab Khan conducted this study, collected data and wrote first draft of the manuscript. Dr. Shahid Ali developed main theme of the study, interpreted results and helped in abstract writing. Asim Khan reviewed literature, helped in model specification and analysis. Waqas Khan helped in model specification and statistical analysis of the manuscript. Dr. Sufyan Ullah Khan helped in writing conclusions, recommendations and corrected references. All authors read and 
approved the final manuscript.

Conflict of interest

All authors declare that there is no conflict of interest.

\section{References}

Ali, S., A. Khan, A. Khan and B. Riaz. 2019. Determinants of technical efficiency of tomato farms in district Peshawar, Khyber Pakhtunkhwa. Sarhad J. Agric., 35(2): 572-578. https://doi. org/10.17582/journal.sja/2019/35.2.572.578

Aigner, D.J.C., A.K. Lovell and P. Schmidt. 1977. Formulation and estimation of stochastic frontier production function model. J. Econ. 6: 21-37. https://doi.org/10.1016/03044076(77)90052-5

Anupama, J., R. Singh and R. Kumar. 2005. Technical efficiency in maize production in Madhya Pradesh: Estimation and implications. Agric. Econ. Res. Rev. 18: 305-315.

Battese, G.E. 1992. Frontier production functions and technical efficiency: A survey of empirical application in agricultural economics. Agric. Econ. 7: 185-208.

Bempomaa,B. and H.D.G.Acquah.2014.Technical efficiency analysis of maize production: Evidence from Ghana.APSTRACT: Appl. Stud.Agribus. Commerce, 8 (1033-2016-84243), 73. https:// doi.org/10.19041/Apstract/2014/2-3/9

Bravo-Ureta, B.E. and A.E. Pinheiro. 1997. Technical, economic and allocative efficiency in peasant farming: Evidence from the Dominican Republic. Dev. Econ. 35: 48-67. https://doi. org/10.1111/j.1746-1049.1997.tb01186.x

Chirwa, E.W., 2007. Sources of technical efficiency among smallholder maize farmers in Southern Malawi. Dep. Econ., Chancellor College, Univ. Malawi, Zomba, Malawi. Wadonda Consult Working Paper WC/01/03, July 2003.

Cochran, W.G., 1977. Sampling Techniques, $3^{\text {rd }}$ Edition. John Wiley and Sons, New York. pp. 37-45.

DFID. 2018. Department for international development annual report and accounts, 20172018.

FAO. 2017. FAOSTAT online statistical service. www.fao.org/faostat

Farrell, M.J., 1957. The measurement of productive efficiency. J. R. Stat. Soc., 120(3): 252-281. https://doi.org/10.2307/2343100

Fatima, H., L. Almas and B. Yasmin. 2016.
Allocative efficiency and profitability analysis of food policy research institute, July, 2011.

GAFSP. 2017. GAFSP annual report 2017, GAFPS coordination unit $1818 \mathrm{~h}$ street, NW Washington.

Geffersa, A.G., F.W. Agbola and A. Mahmood. 2019. Technical adoption and technical efficiency in maize production in rural Ethiopia. Afr. J. Resour. Econ. 14: 184-201.

Geta, E., A. Bogale, B. Kassa and E. Elias. 2013. Productivity and efficiency analysis of smallholder maize producers in southern Ethiopia. J. Hum. Ecol. 41: 67-75. https://doi. org/10.1080/09709274.2013.11906554

GOKP. 2018. Development statistics of Khyber Pakhtunkhwa, 2017-2018. Bureau Stat., Plann. Dev. Dep., Peshawar, GoKP.

GOP. 2012. Agricultural statistics of Pakistan, 2011-12. Minist. Food, Agric. Livest., Econ. Wing, Islamabad, Pakistan.

GOP.2017.Pakistan statistical year book,2017.Pak. Bureau Stat., Stat. Div., Islamabad, Pakistan.

GOP. 2018. Economic survey of Pakistan, 20172018. Econ. advisory wing, Finance Div., Islamabad Pakistan.

Gouse, M., J. Piesse, C.G. Thirtle and C. Poulton. 2009. Assessing the performance of GM maize amongst smallholders in KwaZulu-Natal, South Africa. AgBio Forum. 12(1): 78-89.

Kamau, P.N., 2019. Technical, economic and allocative efficiency among maize and rice farmers under different land-use systems in east African Wetlands. Unpubl. Master Sci. thesis submitted Dep. Agric. Econ., Sch. Agric. Enterp. Dev., Kenyatta Univ., Nairobi, Kenya.

Kidane, A. and E.T. Ngeh. 2015. A comparative analysis of technical efficiency of smallholder tobacco and maize farmers in Tabora, Tanzania. J. Dev. Agric. Econ. 7: 72-79. https://doi. org/10.5897/JDAE2014.0616

Khan,H.2012. Measurement of technical, allocative and economic efficiency of tomato farms in Northern Pakistan. J. Agric. Sci. Technol. 2: 1080-1090.

Koopmans, T.C. 1951. An analysis of production as an efficient combination of activities. In: Activity Analysis of Production and Allocation. John Wiley and Sons, Inc.

Owens, J., 2003. How important is access to ADMARC Markets in Malawi? World Bank, Poverty Reduction Group, Washington, DC. 
Mimeo.

Sapkota, M., N.P. Joshi, R.R. Kattel and M. Bajracharya. 2017. Technical efficiency and its determinants on maize seed production in Palpa district, Nepal. Preprints. 2017: 2017050067. https://doi.org/10.20944/ preprints201705.0067.v1

Singh, D. and R.K. Khosla. 2003. Post-harvest food grain losses in India: A review. Agric. Situation India, 33(8): 499-500.
Uaiene, R.N., 2011. Determinants of agricultural technology adoption in Mozambique. Paper Presented at "Dialogue on Promoting Agricultural Growth in Mozambique." International

Ugochukwu, A.I. and P.W. Phillips. 2018. Technology adoption by agricultural producers: A review of the literature. In: From Agrisci. Agribus. Springer, Cham. pp. 361-377. https:// doi.org/10.1007/978-3-319-67958-7_17 